Research

\title{
Mating changes the subcellular distribution and the functionality of estrogen receptors in the rat oviduct
}

\author{
Pedro A Orihuela*1,2, Lidia M Zuñiga ${ }^{3}$, Mariana Rios ${ }^{4}$, Alexis Parada- \\ Bustamante $^{3}$, Walter D Sierralta ${ }^{5}$, Luis A Velásquez ${ }^{1,2}$ and \\ Horacio B Croxatto ${ }^{1,2,3}$
}

\begin{abstract}
Address: ${ }^{1}$ Laboratorio de Inmunología de la Reproducción, Facultad de Química y Biología, Universidad de Santiago de Chile, Santiago, Chile, ${ }^{2}$ Centro para el Desarrollo en Nanociencia y Nanotecnología-CEDENNA, Santiago, Chile, ${ }^{3}$ Millennium Institute for Fundamental and Applied Biology, Santiago, Chile, ${ }^{4}$ Unidad de Reproducción y Desarrollo, Facultad de Ciencias Biológicas, Pontificia Universidad Católica de Chile, Santiago, Chile and ${ }^{5}$ Instituto de Nutrición y Tecnología de los Alimentos, Universidad de Chile, Santiago, Chile
\end{abstract}

Email: Pedro A Orihuela* - pedro.orihuela@usach.cl; Lidia M Zuñiga - lzunigac@bio.puc.cl; Mariana Rios - mrios@bio.puc.cl; Alexis ParadaBustamante - aparada@uc.cl; Walter D Sierralta - wsierra@inta.cl; Luis A Velásquez - luis.velasquez.c@usach.cl; Horacio B Croxatto - horacio.croxatto@usach.cl

* Corresponding author

Published: 30 November 2009

Reproductive Biology and Endocrinology 2009, 7:139 doi:10.1 186/1477-7827-7-139

This article is available from: http://www.rbej.com/content/7/1/139

(C) 2009 Orihuela et al; licensee BioMed Central Ltd.

This is an Open Access article distributed under the terms of the Creative Commons Attribution License (http://creativecommons.org/licenses/by/2.0), which permits unrestricted use, distribution, and reproduction in any medium, provided the original work is properly cited.
Received: 23 September 2009

Accepted: 30 November 2009

\begin{abstract}
Background: Mating changes the mode of action of I 7beta-estradiol (E2) to accelerate oviductal egg transport from a nongenomic to a genomic mode, although in both pathways estrogen receptors (ER) are required. This change was designated as intracellular path shifting (IPS).

Methods: Herein, we examined the subcellular distribution of ESRI and ESR2 (formerly known as ER-alpha and ER-beta) in oviductal epithelial cells of rats on day I of cycle $(\mathrm{Cl})$ or pregnancy $(\mathrm{PI})$ using immunoelectron microscopy for ESRI and ESR2. The effect of mating on intraoviductal ESR I or ESR2 signaling was then explored comparing the expression of E2-target genes c-fos, brain creatine kinase $(\mathrm{Ckb})$ and calbindin $9 \mathrm{kDa}(\mathrm{sl} 00 \mathrm{~g})$ in rats on $\mathrm{Cl}$ or $\mathrm{PI}$ treated with selective agonists for ESRI (PPT) or ESR2 (DPN). The effect of ER agonists on egg transport was also evaluated on $\mathrm{Cl}$ or PI rats.
\end{abstract}

Results: Receptor immunoreactivity was associated with the nucleus, cytoplasm and plasma membrane of the epithelial cells. Mating affected the subcellular distribution of both receptors as well as the response to E2. In $\mathrm{Cl}$ and PI rats, PPT increased $\mathrm{Ckb}$ while both agonists increased cfos. DPN increased $\mathrm{Ckb}$ and sl00g only in $\mathrm{Cl}$ and PI rats, respectively. PPT accelerated egg transport in both groups and DPN accelerated egg transport only in $\mathrm{Cl}$ rats.

Conclusion: Estrogen receptors present a subcellular distribution compatible with E2 genomic and nongenomic signaling in the oviductal epithelial cells of $\mathrm{Cl}$ and PI although IPS occurs independently of changes in the distribution of ESRI and ESR2 in the oviductal epithelial cells. Mating affected intraoviductal ER-signaling and induced loss of functional involvement of ESR2 on E2-induced accelerated egg transport. These findings reveal a profound influence on the ER signaling pathways exerted by mating in the oviduct. 


\section{Background}

It is well recognized that in the female mammal ovarian steroids, embryonic signals or mating-associated signals regulate egg transport through the oviduct (for review see [1]). In cyclic rats, oocytes reach the uterus approximately $72 \mathrm{~h}$ after ovulation, whereas in pregnant rats embryos take $96 \mathrm{~h}$. Oocytes take $96 \mathrm{~h}$ to traverse the oviduct in rats made pseudopregnant by mechanical stimulation of the cervix in the evening of proestrus, therefore the above difference is dependent on mating-associated signals rather on whether eggs are fertilized or not [2]. Eggs cross the ampullary-isthmic junction $9 \mathrm{~h}$ earlier and egg surrogates move at higher speed in the isthmic segment with most of them arriving earlier to the intramural segment in pregnant rats than in cycling rats [3]. Thus, a broad change occurs in oviductal functioning elicited by mating-associated signals.

A single injection of $17 \beta$-estradiol $\left(\mathrm{E}_{2}\right)$ on day 1 of the cycle or pregnancy shortens oviductal transport of eggs from the normal 72-96 h to less $24 \mathrm{~h}$ [1]. Previously, we demonstrated that inhibitors of RNA and protein synthesis block $\mathrm{E}_{2}$-induced oviductal embryo transport acceleration in pregnant rats, but fail to do so in cyclic rats $[4,5]$. Furthermore, in cyclic rats exogenous $\mathrm{E}_{2}$ activates protein phosphorylation in the oviduct via a nongenomic pathway, since such activation occurs when mRNA synthesis is completely suppressed by $\alpha$-Amanitin [6]. Estradiolinduced phosphorylation is essential for its effect on oocyte transport in cycling rats since local administration of a broad-spectrum inhibitor of protein kinases totally blocks the effect of $E_{2}$ on egg transport $[7,8]$. Thus, $E_{2}$ accelerates oviductal egg transport through nongenomic pathways in cyclic rats, while it does it through genomic pathways in pregnant rats. Recently, this change in pathways has been designated "intracellular path shifting" (IPS) [9]. Further investigation has shown that activity of the enzyme Catechol-O-Methyltransferase (COMT) is higher in the oviduct of cyclic than pregnant rats while OR486 a selective inhibitor of COMT blocked the effect of $\mathrm{E}_{2}$ on oviductal egg transport only in cyclic rats suggesting that decreased activity of oviductal COMT induced by mating is one of the underlying mechanisms of IPS [9]. Although the physiological relevance of IPS has not been clearly established it is probable that decrease in the COMT activity induced by mating in the oviduct protects the embryos from the deleterious effect that methoxyestradiols exert during the first stages of development [10].

Estrogens induce cellular changes in their target organs through several different mechanisms that involve activation of estrogen receptors (ER). The two main forms of ER, ESR1 and ESR2 (formerly known as ER- $\alpha$ and ER- $\beta$ ), have distinct tissue expression patterns in both humans and rodents [11]. The antiestrogen ICI 182780 blocks $\mathrm{E}_{2}$ induced egg transport acceleration in cyclic and pregnant rats [7] indicating that ER participates in both the genomic and the nongenomic pathways involved in the kinetic action of $\mathrm{E}_{2}$ on the oviduct. However, we have found that levels of ESR1 and ESR2 mRNA and protein in oviducts of pregnant rats were similar to those oviducts of cycling rats, suggesting that IPS is not explained by changes in the expression of ER in the oviduct [12]. Herein, we determined the effect of mating on subcellular distribution and functionality of ESR1 and ESR2 in the rat oviduct. First, we compared immunoreactivity of both ER associated to cell membrane, cytoplasm and nucleus between epithelial cells of the ampullary and isthmic segments of cyclic and pregnant rats following treatment with E2. We also determined the effect of selective agonists for ESR1 (PPT) or ESR2 (DPN) on mRNA levels of three E2-inducible genes c-fos, brain creatine kinase (Ckb) and calbindin $9 \mathrm{kDa}(\mathrm{s} 100 \mathrm{~g})[13,14]$ in the oviduct of pregnant and cyclic rats. Additionally, the role of ESR1 and ESR2 on oviductal egg transport was evaluated in cyclic or pregnant rats treated with PPT or DPN.

\section{Methods \\ Animals}

Sprague-Dawley rats (bred in house) weighing 200-260 g were used. Animals were kept under controlled temperature $\left(21-24^{\circ} \mathrm{C}\right)$, and lights were on from 0700 to $2100 \mathrm{~h}$. Water and pelleted food were supplied ad libitum. The phases of the estrous cycle were determined by daily vaginal smears [15] and all females were used after showing two consecutive 4-day cycles. Females in pro-estrus were kept either isolated or caged with fertile males. The following day (estrus) was designated as $\mathrm{C} 1$ in the first instance and day P1 in the second, provided spermatozoa were found in the vaginal smear. The care and manipulation of the animals was done in accordance with the ethical guidelines of our institution.

\section{Treatments}

Systemic administration of $E_{2}$

On $\mathrm{C} 1$ or P1 $\mathrm{E}_{2} 5 \mu \mathrm{g}$ was injected subcutaneously (s.c.) as a single dose dissolved in $0.1 \mathrm{~mL}$ propylene glycol. Control rats received propylene glycol alone.

\section{Local administration of selective agonist of ESRI (PPT) or ESR2 (DPN)}

PPT (1,3,5-tris(4-hydroxyphenyl)-4-propyl-1H-pyrazole, Sigma Chem. CO, St. Louis, MO) [16] or DPN (Diarylpropionitrile, Tocris Cookson Inc. Ellisville, MO) [17] were injected into each bursa at a concentration of 7.5, 22.5 or $67.5 \mathrm{ng} / \mu \mathrm{L}$ in DMSO 1\%. Control rats received the corresponding vehicle alone. Since the range of effective doses of PPT and DPN given systemically is between $2.5 \mu \mathrm{g} / \mu \mathrm{L}$ $250 \mu \mathrm{g} / \mu \mathrm{L}[18,19]$ we considered appropriate diminished 
these doses to approximately 1000 -fold for local (intrabursal) injection. To our knowledge these doses of PPT or DPN did not change the plasmatic $\mathrm{E}_{2}$ and Progesterone level in the rat.

\section{Animal surgery and assessment of egg transport}

Intrabursal administration of agonists, which minimizes the dose needed to affect the oviduct without systemic effects, was performed on C1 or P1 as previously described [5]. At this time, ovulation has already taken place, so this treatment cannot affect the number of oocytes ovulated. Egg transport was evaluated as previously published $[2,4,5]$. Twenty-four hours after treatment, animals were sacrificed and their oviducts were flushed individually with saline. Flushing was examined under low-power magnification (25x), and the number of eggs found was recorded.

\section{Real-time PCR}

Whole oviducts on $\mathrm{C} 1(\mathrm{~N}=4)$ or P1 $(\mathrm{N}=4)$ were dissected and flushed to avoid contamination with oocytes or embryos mRNA. Oviductal RNA was isolated using Trizol Reagent (Invitrogen, Gaithersburg, MD) and $1 \mu \mathrm{g}$ of total RNA of each sample was treated with Dnase I Amplification grade (Invitrogen). The single-strand cDNA was synthesized by reverse transcription using the Superscript III Reverse Transcriptase First Strand System for RT-PCR (Invitrogen), according to the manufacturer's protocol. The Light Cycler instrument (Roche Diagnostics, GmbH Mannheim, Germany) was used to quantify the relative gene expression of c-fos, Ckb or s100g in the oviduct of cyclic and pregnant rats; Gapdh was chosen as the housekeeping gene for load control because we have previously demonstrated that $E_{2}$ or pregnancy did not affect its expression [20]. The SYBR ${ }^{\circledast}$ Green I double-strand DNA binding dye (Roche Diagnostics) was the reagent of choice for these assays. Primers for $c$-fos were 5' CCG AGA TTG CCA ATC TAC TG 3' (sense) and 5' AGA AGG AAC CAG ACA GGT CC $3^{\prime}$ (antisense), Ckb 5' AAG CTG GCA GTA GAA GCC CT 3' (sense) 5' TTG TCG AAG AGG AAG TGG TC 3 ' (antisense), s100g 5' GGC AGC ACT CAC TGA CAG C 3' (sense) 5' CAG TAG GTG GTG TCG GAG C 3'(antisense) and for Gapdh were 5' ACC ACA GTC CAT GCC ATC AC 3' (sense) and 5' TCC ACC ACC CTG TTG CTG TA 3' (antisense). The thermal cycling conditions included an initial activation step at $95^{\circ} \mathrm{C}$ for $25 \mathrm{~min}$, followed by 40 cycles of denaturizing and annealing-amplification $\left(95^{\circ} \mathrm{C}\right.$ for $15 \mathrm{sec}, 60^{\circ} \mathrm{C}$ for $15 \mathrm{sec}$ and $72^{\circ} \mathrm{C}$ for 30 sec) and finally one cycle of melting $\left(95^{\circ}\right.$ to $\left.60^{\circ} \mathrm{C}\right)$. To verify specificity of the product, amplified products were subject to melting curve analysis as well as electrophoresis, and product sequencing was performed to confirm identity as described by Muscillo et al [21]. The expression of transcripts was determined using a method previously reported $[22,9]$.

\section{Immunoelectron microscopy}

Oviducts from vehicle and $\mathrm{E}_{2}$-treated rats were separated into ampulla and isthmus and the excess mucus was removed in each segment by flushing with $50 \mu \mathrm{L}$ saline. Both segments were fixed in $4 \%$ freshly depolymerised paraformaldehyde, $0.5 \%$ glutaraldehyde in phosphate buffer $\mathrm{pH} 7.40 .1 \mathrm{M}$ containing saccharose $0.1 \mathrm{M}$, DMSO $1 \%$ and $\mathrm{CaCl}_{2} 1 \%$ for $2-4 \mathrm{~h}$ at room temperature. The fixed samples were washed three times with phosphate buffer, dehydrated in a graded ethanol series and infiltrated with LR Gold (Plano, München, FRG). Subsequently, the samples were transferred to gelatine capsules filled with $0.8 \%(\mathrm{w} / \mathrm{v})$ benzoyl peroxide in LR Gold and kept for polymerization at a pressure of $500 \mathrm{mmHg}$. The blocks were cured for 1-2 days at room temperature before sectioning with a Sorvall-2000 ultramicrotome using a diamond knife. The sections (50-80 nm) were mounted on formvar-coated nickel grids and incubated on droplets of 0.1 M glycine in PBS pH 7.6, and subsequently blocked with $1 \%$ bovine foetal serum for $2 \mathrm{~h}$ at room temperature. The grids were then incubated for $2 \mathrm{~h}$ with a rabbit antiESR1 (MC-20, Santa Cruz Biotechnology, Santa Cruz, CA) or anti-ESR2 (clone 68-4, Chemicon International, Billerica, MA) at 1:50 dilution. After washing with PBS, the preparations were incubated for $1 \mathrm{~h}$ with goat anti-rabbit immunoglobulin conjugated to $10 \mathrm{~nm}$ gold particles (Kirkegaard \& Perry Laboratories Inc, Gaithersburg, MD) diluted 1:30. Sections were washed and contrasted with Reynolds stain [23]. All sections were examined using a Phillips-TECNAI 12 BIOTWIN EM Microscope (FEI Company, Hillsboro, OR) at $80 \mathrm{kV}$. As negative controls the primary antibody was replaced by rabbit preimmune serum or oviductal samples without prior incubation with anti-ESR1 antibody or anti-ESR2 antibody were also included. For further validation we also performed immunoelectron microscopy of the isthmic segment from vehicle and $E_{2}$-treated rats using a mouse anti-ESR1 from another company (H-151, Calbiochem, La Jolla, CA), as primary antibody diluted 1:30. Furthermore, we used gold-labeled particles of $40 \mathrm{~nm}$ (Kirkegaard \& Perry Laboratories Inc) to obtain photomicrographs at low magnification for show unspecific background labeling in the oviductal lumen. At least ten areas of $63 \mu \mathrm{m}^{2}$ from different epithelial cells and different sections of an oviduct were photographed and the photomicrographs were digitalized in an iBook computer (Apple Computer Inc, Cupertino, CA), and gold particles present only in the cells were counted using the image analysis software Adobe Photoshop 7.0 (Adobe Systems Inc, San Jose, CA) by an observer blinded to the treatment groups. The results of the immunolabeling are presented as the quotient of the number of gold particles present divided by the area and cell number inspected [24]. 


\section{Statistical analysis}

The results are presented as mean \pm SE. Overall analysis was done by Kruskal-Wallis test, followed by Mann-Whitney test for pair-wise comparisons when overall significance was detected.

\section{Results}

Distribution of ESRI and ESR2 in epithelial cells of mated and non-mated rat oviducts treated with $E_{2}$

At 09:00 h of C1 or P1, 8 rats were injected with $\mathrm{E}_{2} 5 \mu \mathrm{g}$ or vehicle and $3 \mathrm{~h}$ later they were sacrificed and their oviducts were separated into ampulla and isthmus and processed for immunoelectron microscopy. Representative photomicrographs of the subcellular distribution of ESR1 and ESR2-reacting gold particles in oviductal epithelial cells of the rat are shown in Figures 1, 2 and 3. Receptor immunoreactivity was found associated with the nucleus, cytoplasm and plasma membrane, including cilia, of the epithelial cells. Data for subcellular distribution of ESR1 in ampulla and isthmus are shown in Figure 4. Mating increased the immunoreactivity of ESR1 in the plasma membrane and cytoplasm of the ampullary segment although it did not affect the ESR1 immunoreactivity in the isthmus. In cyclic rats, $\mathrm{E}_{2}$ treatment increased the density of ESR1 labeling in all three compartments from both segments, except the nucleus of the isthmic segment, whereas in pregnant rats a major increase in labeling was observed only in the cytoplasm of the isthmic segment.
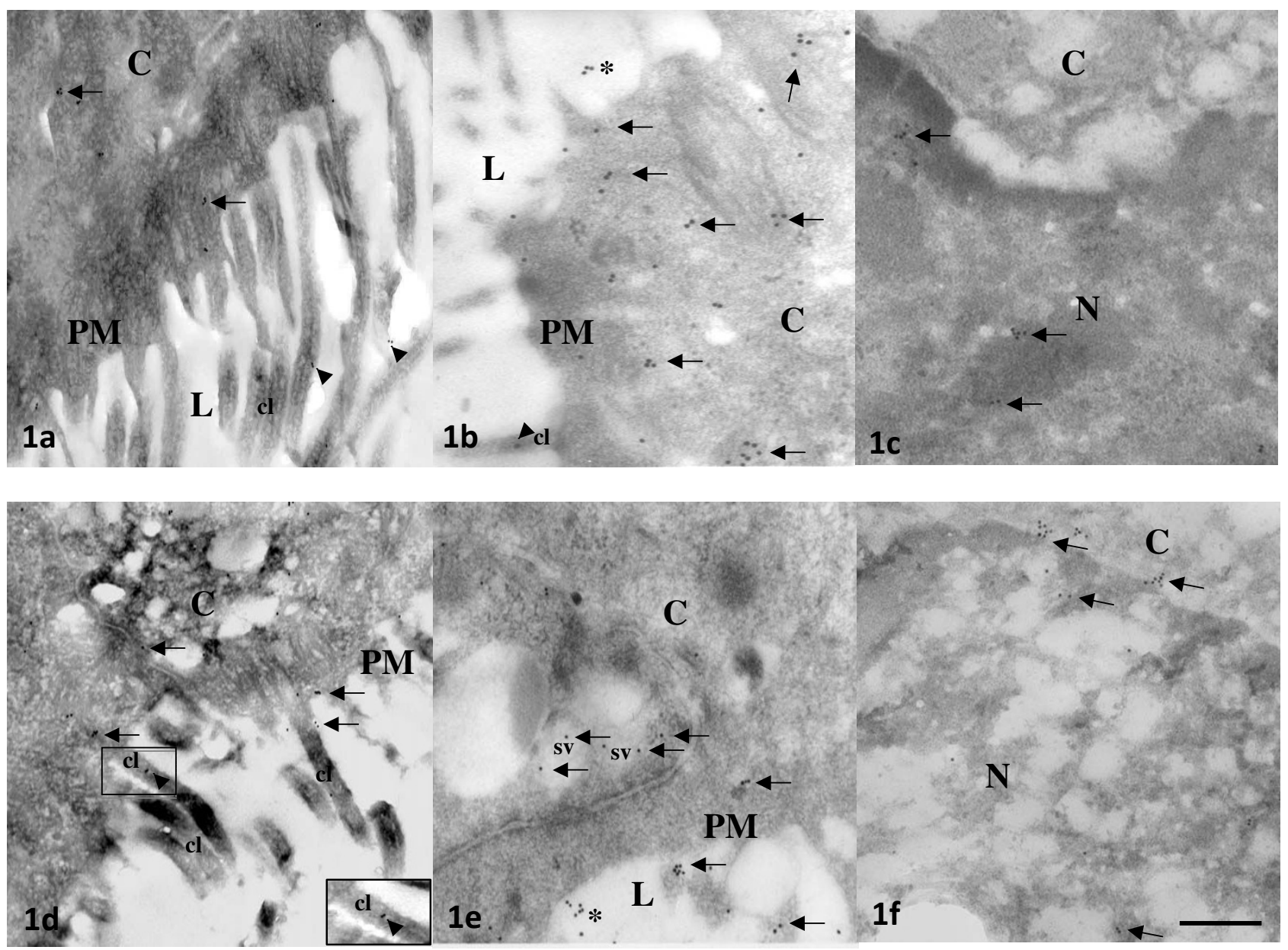

Figure I

Representative photomicrographs of oviductal epithelial cells processed by immunoelectron microscopy with gold labeled-antibodies of $10 \mathrm{~nm}$ for ESRI (a-c) or ESR2 (d-f). Ampullary and isthmic sections of cyclic (a-c) and pregnant (d-f) rats are shown in the upper and lower panels, respectively. Arrows denotes ESRI-or ESR2 reacting gold particles in the epithelial cells. Arowheads emphasize the association of estradiol receptor immunoreactivity with cilia (cl, see insert in d). Asterisks indicate unspecific background laleling. Bar: $0.5 \mu \mathrm{m}$. $\mathbf{P M}=$ plasma membrane, $\mathbf{C}=$ cytoplasm, $\mathbf{N}=$ nucleus, $\mathbf{L}=$ lumen, $\mathbf{S V}$ = secretory vesicle. 

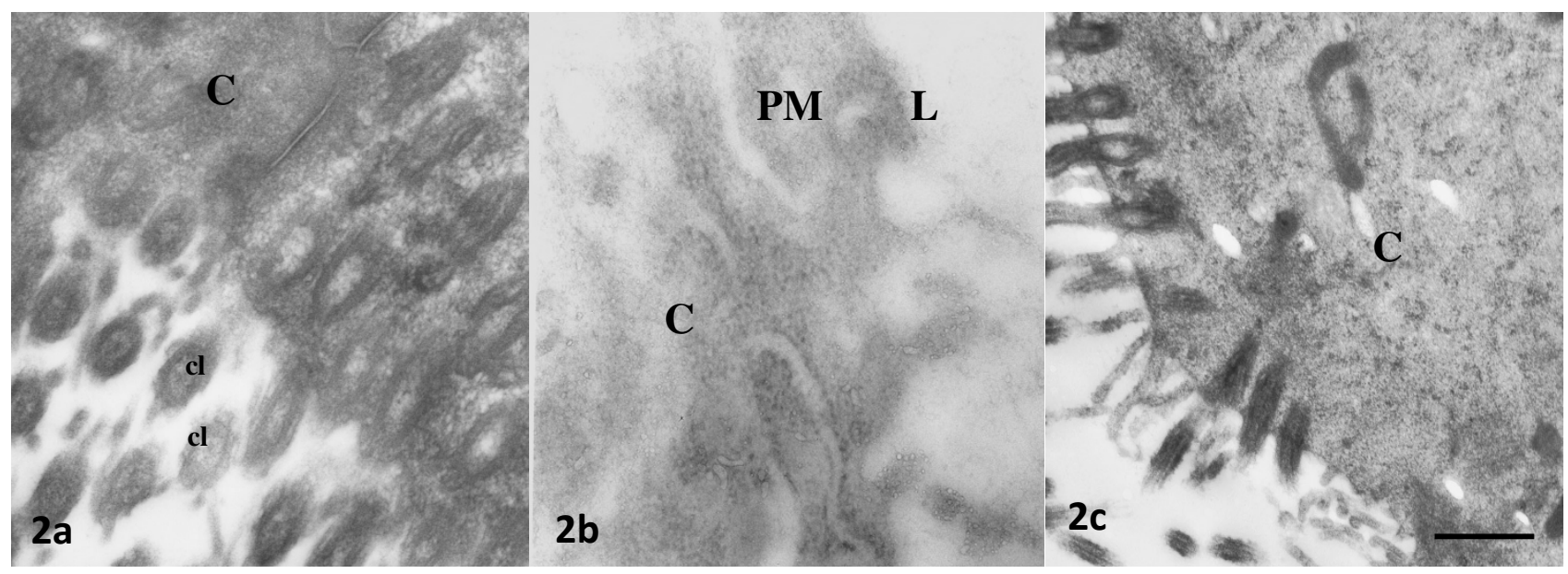

Figure 2

Representative photomicrographs of oviductal epithelial cells processed by immunoelectron microscopy without prior incubation with anti-ESRI antibody (a) or anti-ESR2 antibody (b), or incubated with rabbit preimmune serum (c). Bar: $0.5 \mu \mathrm{m}$. $\mathbf{P M}=$ plasma membrane, $\mathbf{C}=$ cytoplasm, $\mathbf{L}=$ lumen, $\mathbf{c l}=$ cilia. Bar: $0.5 \mu \mathrm{m}$.

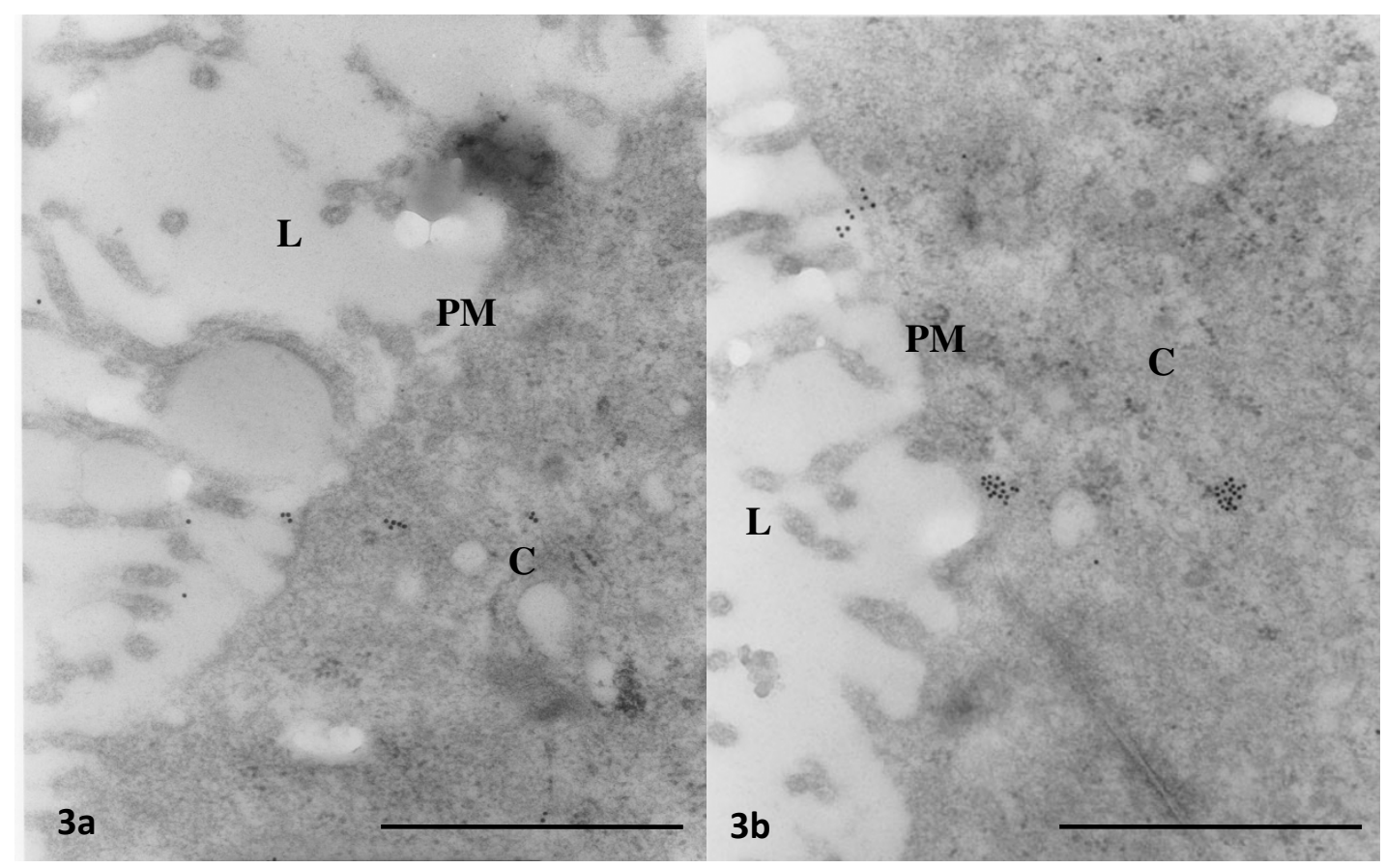

\section{Figure 3}

Representative photomicrographs at low magnification of oviductal epithelial cells processed by immunoelectron microscopy with gold labelled-antibodies of $\mathbf{4 0} \mathbf{~ n m}$ for ESR I (a) or ESR2 (b). Arrows denotes ESRI-or ESR2 reacting gold particles in the epithelial cells. Note scarce unspecific background laleling. Bar: $0.5 \mu \mathrm{m}$. PM = plasma membrane, $\mathbf{C}=$ cytoplasm, $\mathbf{L}=$ lumen. 


\section{ER- $\alpha$ \\ Cyclic}
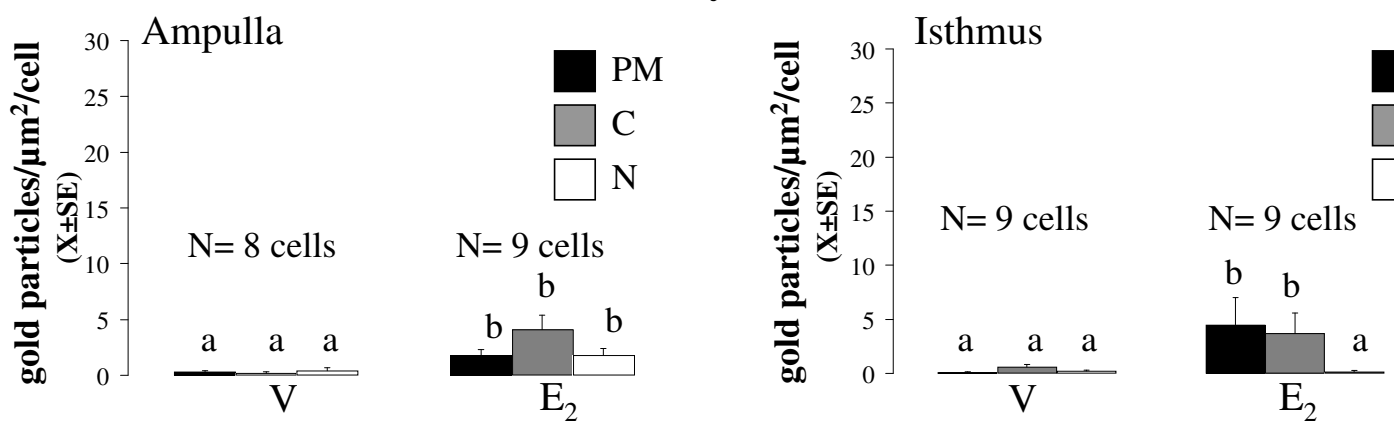

Pregnant
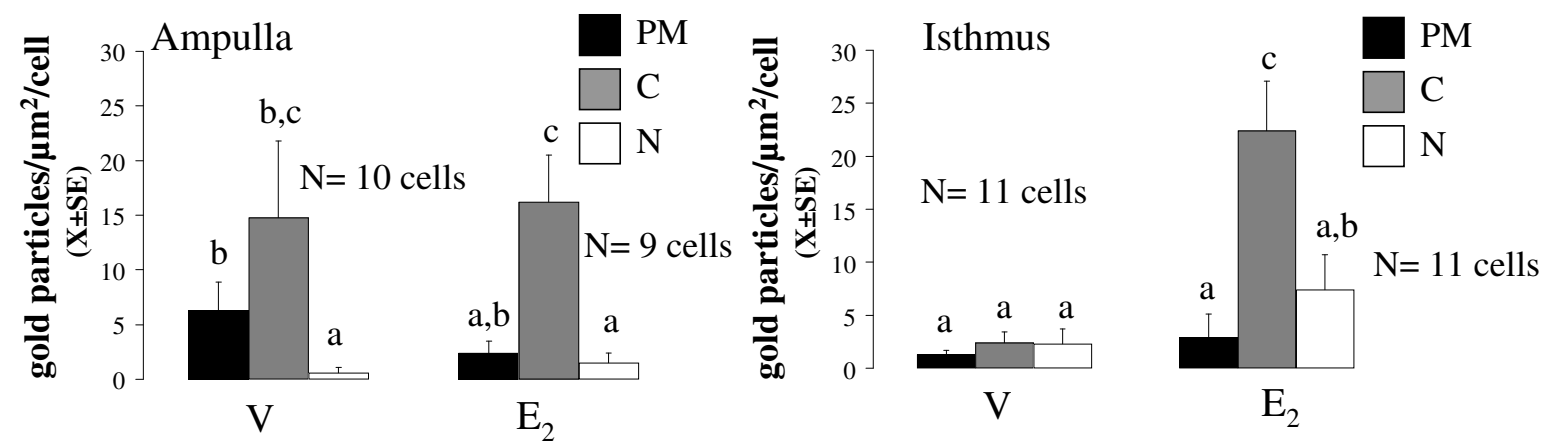

\section{Figure 4}

Mean number of the density of gold particles $(X \pm S E)$ observed for ESRI in the plasma membrane (PM), cytoplasm (C) and nucleus (N) of epithelial cells of oviductal ampulla (A) and isthmus (I) from rats on day $I$ of the cycle or pregnancy, 3 hours after treatment with oestradiol. Means with different letters are significantly different from each other within each graph $(P<0.05) . a \neq b \neq c$. Replicas of this experiment are stated in the figure.

Mating decreased immunoreactivity of ESR2 in the cytoplasm of the ampullary and isthmic segments although it increased labeling of ESR2 in the plasma membrane of the isthmus. In cyclic rats, $\mathrm{E}_{2}$ decreased ESR2 density in the cytoplasm in the ampulla and in the nucleus of the isthmus, whereas in pregnant rats, $E_{2}$ increased the density of ESR2 labeling in the cytoplasm in the ampulla and decreased it in the plasma membrane and nucleus in the isthmus (Figure 5). The results using the mouse anti-ESR1 were similar to those obtained with the rabbit anti-ESR1 (not shown). Furthermore, low unspecific background labeling of gold particles was found in the lumen of epithelial cells in control experiments without primary antibody or incubation with rabbit preimmune serum (see figures 2 and 3). All this supports the specificity in the recognition of ER immunoreactivity.
Effect of selective agonist of ESRI or ESR2 on the level of $\mathrm{c}$-fos, Ckb and s $100 \mathrm{~g}$ in the oviduct of pregnant and cycle rats

Rats on $\mathrm{C} 1(\mathrm{~N}=4)$ or P1 $(\mathrm{N}=4)$ were locally treated with $67.5 \mathrm{ng} / \mu \mathrm{L}$ of PPT or DPN and $3 \mathrm{~h}$ later oviducts were excised and their total RNA were processed by RT-PCR using specific primers for c-fos, Ckb, s100g or Gapdh as described above. Figure 6 shows that in cyclic rats oviductal levels of $c$-fos, $C k b$ and $s 100 \mathrm{~g}$ were similar while in pregnant rats levels of $C k b$ were major than $c-f o s$ and $s 100 g$. PPT increased 5-fold and 3-fold the levels of $\mathrm{Ckb}$ and c-fos in cyclic and pregnant rats while $\mathrm{s} 100 \mathrm{~g}$ was not affected in both conditions. In cyclic rats, DPN increased 4- and 5fold $\mathrm{Ckb}$ and c-fos respectively, while in pregnant rats DPN increased 2.5 fold c-fos and 2-fold s100g. 


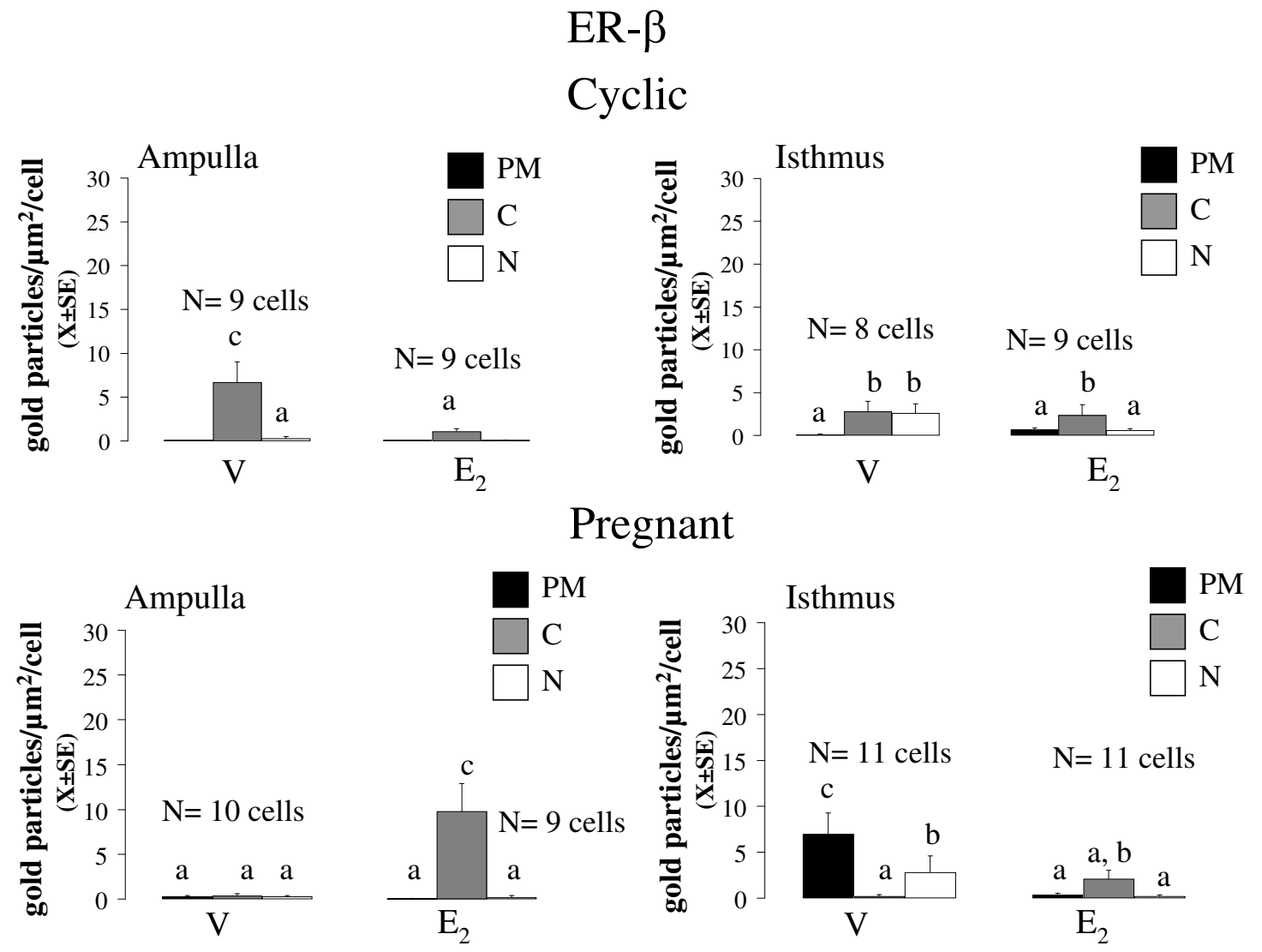

Figure 5

Mean number of the density of gold particles $(X \pm$ SE) observed for ESR2 in the plasma membrane (PM), cytoplasm (C) and nucleus (N) of epithelial cells of oviductal ampulla (A) and isthmus (I) from rats on day $I$ of the cycle or pregnancy, 3 hours after treatment with oestradiol. Means with different letters are significantly different from each other within each graph $(P<0.05) . a \neq b \neq c$. Replicas of this experiment are stated in the figure.

Effect of selective agonist of ESRI or ESR2 on oviductal egg transport in mated and non-mated rats

Rats on C1 or P1 were locally treated with PPT or DPN 7.5, 22.5 or $67.5 \mathrm{ng} / \mu \mathrm{L}$ and $24 \mathrm{~h}$ after treatment egg transport was evaluated in all groups as described above. The mean number $(\mathrm{X} \pm \mathrm{SE})$ of eggs recovered from the oviducts of control or treated groups are shown in figure 7 . Intrabursal administration of PPT decreased the number of eggs recovered from the oviduct in cyclic and pregnant rats although at lower doses in cyclic rats. Administration of DPN decreased the number of eggs only in $\mathrm{C} 1$, but not in P1 rats.

\section{Discussion}

An important variable that influences $\mathrm{E}_{2}$ actions on its target cells is the differential distribution of ESR1 and ESR2. Previous works have reported presence of ESR1 and ESR2 in the epithelium and smooth muscle layers of the amp- ullary and isthmic segments of the rat oviduct $[25,26]$. Here, we show for the first time that ESR1 and ESR2 were found associated to the plasma membrane, cytoplasm and nucleus of the epithelial cells of both oviductal segments in the rat. This is in agreement with previous immunoelectron microscopy studies reporting localization of ESR1 in non-nuclear sites in other cell types $[27,28]$. Other studies have also shown the presence of ESR1 and ESR2 in non-nuclear sites of various cell types using western blot or ligand-blot of subcellular enriched fractions [29-31]. Ligand activation of ER associated to cell membrane and cytoplasm can modulate downstream pathways that induce discrete signaling responses, including stimulation of adenylyl cyclase in breast and vascular tissues [32,33], activation of $\mathrm{Ca}^{2+}$ flux in arterial smooth muscle [34] or the cascade Src/Ras/ERK [35]. Our findings provide evidence of the presence of multiple pools of ER that could initiate genomic and nongenomic responses to 


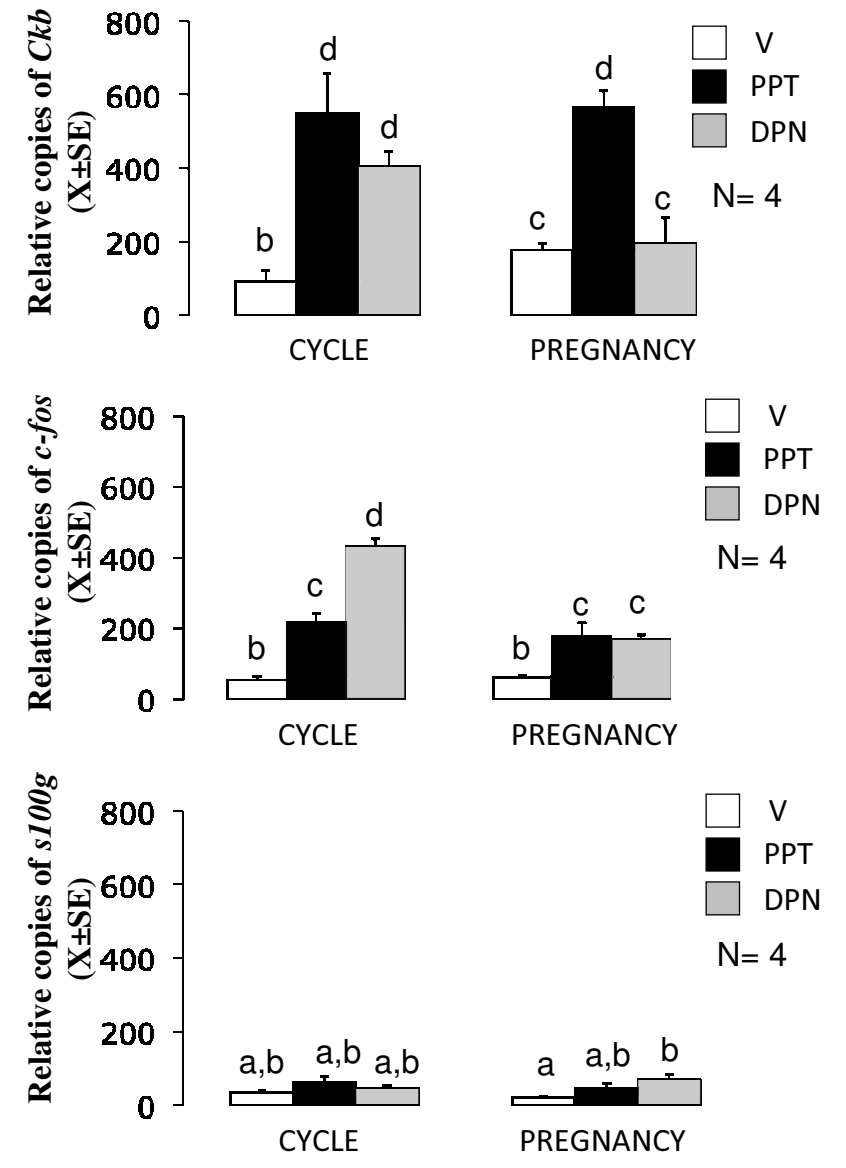

Figure 6

Mean number of the relative copies (X $\pm \mathrm{SE}$ ) of $\mathrm{Ckb}$, $c-$ fos and $5100 \mathrm{~g}$ in the rat oviducts on day $I$ of cycle or pregnancy following intrabursal treatments with the selective agonists of ESRI, PPT or ESR2, DPN. V:

vehicle of drugs, PPT: $67.5 \mathrm{ng} / \mu \mathrm{L}$, DPN: $67.5 \mathrm{ng} / \mu \mathrm{L}$. All treatments were given $3 \mathrm{~h}$ before autopsy. Each experiment consisted of 4 replicas. Means with different letters are significantly different from each other $(P<0.05), a \neq b \neq c \neq$ d.

$\mathrm{E}_{2}$. Furthermore, the data reported here show a dynamic behavior of these ER pools in response to mating-associated signals and to an $\mathrm{E}_{2}$ pulse.

Since mating induces IPS we expected that pregnant and cyclic rats would exhibit different ER subcellular distribution, e.g. higher ESR1, ESR2 or both in the nuclear compartment. However, quantitative analyses showed that mating increased the number of both receptors only in the non-nuclear compartments. Furthermore, when $\mathrm{E}_{2}$ was administered to pregnant or cyclic rats receptor immunoreactivity also accumulated in the non-nuclear compartments. Thus, IPS occurs independently of the changes in the distribution of ESR1 and ESR2 in the oviductal epithe- lial cells induced by mating. ESR1 and ESR2 are also expressed in the mucosa and muscle layer of the rat oviduct $[25,26]$ so that it is possible that mating stimulates accumulation of ER in the nuclear compartment of other cell types. The changes described in gold particle density may reflect either change in antibody accessibility to immunoreactive epitopes or true changes in the expression level of ER. The current data does not allow to distinguish between these two possibilities but increases up to ten fold 3 hours after $E_{2}$ administration seem more plausible as a result of ER dissociation from scaffolding proteins than a result of de novo synthesis. In fact, previously we have found that levels of ESR1 and ESR2 mRNA and protein in whole oviducts of pregnant rats were similar to those in oviducts of cycling rats, suggesting that mating does not regulate global expression of ER in the oviduct [12].

We observed different responses in the subcellular distribution of ER in the epithelial cells of the two oviductal segments. It is known that the relative proportion between ciliated and secretory epithelial cells varies considerably from ampulla to isthmus [36] so that is probable that mating-associated signals may have acted differentially on these two cell types. Further analysis that segregates the responses of ciliated from secretory epithelial needs to be done. It has been reported that in the rat, $\mathrm{E}_{2}$ acts only in the isthmic segment to accelerate egg transport [37] while that isthmus-specific apoptosis of epithelial cells and activation of cilia-localized ESR2A induced by clomiphene citrate act in parallel to block egg transport [19]. Thus, it is probable that differences in the distribution of ESR1 and ESR2 between ampulla and isthmus could reflect specific contribution of these segments to signals provided by $\mathrm{E}_{2}$ to regulate egg transport. Furthermore, we did not discard the possibility that $E_{2}$ acts directly on the smooth muscle cells because it has been found presence of ESR1 and ESR2 in the myosalpinx of the rat $[25,26]$.

Interestingly, ESR1 and ESR2 were also observed associated with the cilia of epithelial cells (see insert in figure 1d). Estradiol regulates differentiation and dedifferentiation of ciliated cells of the mammalian oviduct [38]. Furthermore, follicular fluid of human pre-ovulatory follicles containing high concentrations of estradiol and progesterone increased the ciliary beat frequency of human oviductal ciliated cells [39]. Our findings suggest that $E_{2}$ could regulate ciliary activity directly through a nongenomic mechanism probably involving phosphorylation/dephosphorylation of some proteins (e.g. tubulin or dynein) present in this structure. Recently, it has been shown that ESR2 is colocalized with $\beta$-tubulin at stem portion of the cilia of the oviductal epithelial cells in immature rats [40]. Additionally, gold particles for ESR1 and ESR2 were found 
Cyclic

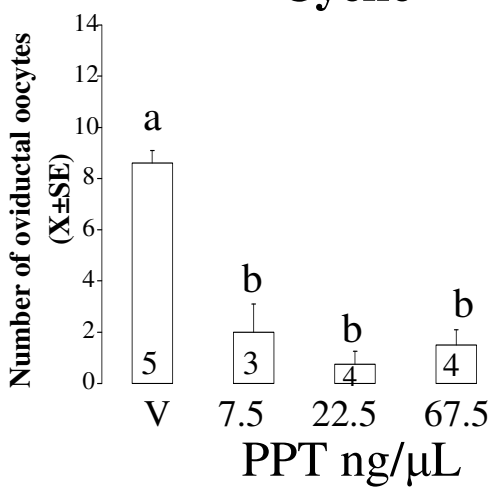

Cyclic

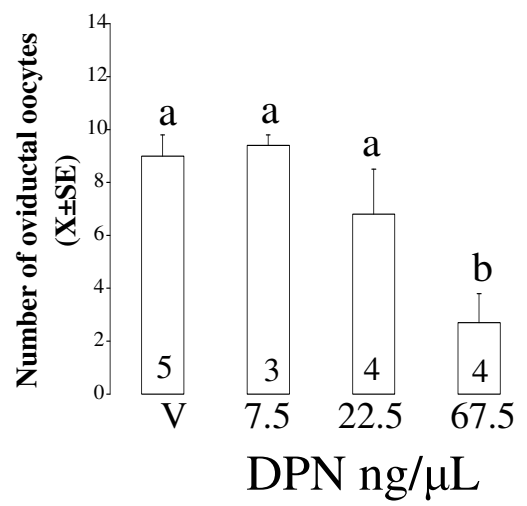

Pregnant

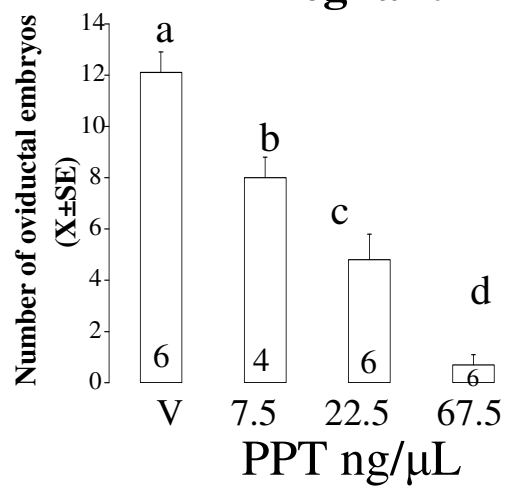

\section{Figure 7}

Mean number of eggs $(X \pm S E)$ recovered from rat oviducts on day 2 of the cycle or pregnancy, $24 \mathrm{~h}$ after intrabursal treatment with different doses of the selective agonists of ESRI, PPT or ESR2, DPN. Figures inside the bars indicate the number of animals used. Means with different letters are significantly different from each other within each graph, $a \neq b \neq c(P<0.05)$.

associated to secretory vesicles. This corroborates previous works reporting localization of ESR1 and ER2 in the rough endoplasmic reticulum and secretory vesicles of the female rat pituitary cells [41]. Although, the biological significance of the localization of ESR1 and ESR2 in secretory vesicles remains to be determined it is probable that a Golgi-dependent pathway could exist for translation of ER that could be translocated into the plasma membrane and mediate nongenomic responses [41].

In other estrogen-sensitive tissues ER subtype expression is differentially regulated by $\mathrm{E}_{2}$. In the human vena cava, $\mathrm{E}_{2}$ down-regulates ESR1 expression [42] while deprivation of $E_{2}$ in the cerebral microvessels of ovariectomized rats is associated with a decrease in the expression of both isoforms and $\mathrm{E}_{2}$ replacement up-regulates ESR1 but does not affect expression of ESR2 [43]. In ovine endothelial cells, short-term treatment with $\mathrm{E}_{2}$ down-regulates ESR1, but not ESR2 while long-term treatment up-regulates ESR1 and down-regulates ESR2 expression [44]. Our findings provide the first evidence that $\mathrm{E}_{2}$ is able to differentially regulate not just the expression level, but also the subcellular distribution of ESR1 and ESR2 in a target cell. We also observed different responses in the expression of three $\mathrm{E}_{2}$-associated signaling genes, $c-f o s, C k b$ and $s 100 g$, in the oviduct of pregnant and cyclic rats when ESR1 or ESR2 was activated. Moreover, activation of ESR1 or ESR2 increased expression of $c$-fos although mating only blunted the effect of ESR2. This indicates that matingassociated signals modulate intraoviductal signalling of both ER providing evidence that mating may change the functional role of these receptors in the rat oviduct. On 
the other hand, the role of $c-f o s, C k b$ or $s 100 \mathrm{~g}$ on IPS induction or $\mathrm{E}_{2}$-induced egg transport acceleration needs to be disclosed.

Given that PPT is 400-fold more selective and DPN is only 70-fold more selective for ESR1 an ESR2 respectively, it was not surprisingly that PPT would be more effective to accelerate oviductal egg transport than DPN in cyclic rats. However, mating decreased effectiveness of PPT and blocked the effect of DPN. Probably, the nongenomic pathway by which $E_{2}$ accelerates egg transport operates through activation of either ESR1 and ESR2 while the genomic pathway only operates through ESR1. The fact that IPS is associated with suppression of ESR2 involvement in the kinetic effect of $E_{2}$ in the oviduct indicate that mating exerts a profound influence on the biology of ER in a target organ of $E_{2}$ that merits further investigation.

Shao et al [19] have reported that subcutaneous administration of DPN retard egg transport in the rat. In this study, immature animals were treated, prior to DPN administration, with gonatrophins to mimic the endogenous luteneizing hormone surge. Probably, this treatment could have affected the response of the oviduct to DPN. Another factor is that we recorded the number and distribution of eggs in the genital tract within the first 24 $\mathrm{h}$ after treatment. In order to detect whether PPT or DPN delay egg transport autopsies should be performed on day 4 or 5 of cycle or pregnancy respectively, but this was not done.

\section{Conclusion}

Estrogen receptors ESR1 and ESR2 present a subcellular distribution in oviductal epithelial cells that is compatible with genomic and nongenomic actions of $\mathrm{E}_{2}$ in the rat oviduct. Mating is associated with changes in the basal and $\mathrm{E}_{2}$-induced subcellular distribution of ESR1 and ESR2 in these cells although it did not clearly explain IPS. Furthermore, mating affected signaling of both ER in the oviduct and induced loss of functional involvement of ESR2 on $\mathrm{E}_{2}$-induced accelerated egg transport. These findings reveal a profound influence on the intraoviductal ER signalling pathways exerted by mating.

\section{Competing interests}

The authors declare that there is no conflict of interest that could be perceived as prejudicing the impartiality of the research reported.

\section{Authors' contributions}

PAO participated in the design of the study, in directing and completing all experimental analysis and in writing the manuscript. LMZ, MR, APB performed the sampling of the animals, carried out the Real-Time PCR, intrabursal injections of drugs and assessment of the egg transport.
WDS collaborate in the design of the studies of the immunomicroscopy of ESR1 and ESR2 and quantification of gold particles for ESR1 and ESR2. LV and HBC participated in planning experiments and contributed to drafting the manuscript. All authors have read and approved the final manuscript.

\section{Acknowledgements}

This work was supported by grants received from FONDECYT 10303 I5, 1080523, PROGRESAR (PRE 004/2003) and Proyecto BASAL FB0807.

\section{References}

I. Croxatto HB: Physiology of gamete and embryo transport through the Fallopian tube. Reprod Biomed Online 2002, 4:160-169.

2. Villalón M, Ortiz ME, Aguayo C, Muñoz J, Croxatto HB: Differential transport of fertilized and unfertilized ova in the rat. Biol Reprod 1982, 26:337-341.

3. Müller AL, Ortiz ME, Ambriz GD, Andrade YN, Croxatto HB: Mating associated signals have profound effects on ovum transport parameters in rats. Placenta 2005, 27:A57.

4. Ríos M, Orihuela PA, Croxatto HB: Intraoviductal administration of ribonucleic acid from estrogen-treated rats mimics the effect of estrogen on ovum transport. Biol Reprod 1997, 56:279-283.

5. Orihuela PA, Croxatto HB: Acceleration of oviductal transport of oocytes induced by estradiol in cycling rats is mediated by nongenomic stimulation of protein phosphorylation in the oviduct. Biol Reprod 200I, 65:238-1245.

6. Orihuela PA, Ríos M, Croxatto HB: Disparate effects of estradio on egg transport and oviductal protein synthesis in mated and cyclic rats. Biol Reprod 200I, 65: I 232-I 237.

7. Orihuela PA, Parada-Bustamante A, Cortés PP, Gatica C, Croxatto HB: Estrogen Receptor, Cyclic Adenosine Monophosphate, and Protein Kinase A Are Involved in the Nongenomic Pathway by Which Estradiol Accelerates Oviductal Oocyte Transport in Cyclic Rats. Biol Reprod 2003, 68: I225-123I.

8. Orihuela PA, Parada-Bustamante A, Zuñiga LM, Croxatto HB: Inositol triphosphate participates in an oestradiol nongenomic signalling pathway involved in accelerated oviductal transport in cycling rats. J Endocrinol 2006, I88:579-588.

9. Parada-Bustamante A, Orihuela PA, Ríos M, Navarrete-Gómez PA, Cuevas CA, Velasquez LA, Villalón MJ, Croxatto HB: Catechol-omethyltransferase and methoxyestradiols participate in the intraoviductal nongenomic pathway through which estradiol accelerates egg transport in cycling rats. Biol Reprod 2007, 77:934-94I.

10. Lattanzi ML, Santos CB, Mudry MD, Baranao JL: Exposure of bovine oocytes to the endogenous metabolite 2-methoxyestradiol during in vitro maturation inhibits early embryonic development. Biol Reprod 2003, 69:1793-1800.

II. Hyder SM, Chiappetta C, Stancel GM: Synthetic estrogen I7alpha-ethinyl estradiol induces pattern of uterine gene expression similar to endogenous estrogen I 7 beta-estradiol. J Pharmacol Exp Ther 1999, 290:740-747.

12. Orihuela PA, Zuñiga LM, Rios M, Llados C, Sierralta W, Croxatto HB: Estrogen receptors in the rat oviduct. Mol Biol Cell 2004, I 5:

13. Mathieu CL, Mills SE, Burnett SH, Cloney DL, Bruns DE, Bruns ME: The presence and estrogen control of immunoreactive calbindin-D9k in the fallopian tube of the rat. Endocrinology 1989 , I 25:2745-2750

14. Nilsson S, Mäkelä S, Treuter E, Tujague M, Thomsen J, Andersson G, Enmark E, Petterson K, Warner M, Gustafsson JA: Mechanisms of estrogen action. Physiol Rev 200I, 81 : I535-I565.

15. Turner CD: Endocrinology of the ovary. In General Endocrinology 3rd edition. WB Saunders Company. Philadelphia; 1961:365-409.

16. Harris HA, Katzenellenbogen JA, Katzenellenbogen BS: Characterization of the biological roles of the estrogen receptors, $E R \alpha$ and $E R \beta$, in estrogen target tissues in vivo through the use of an $E R \alpha$-selective ligand. Endocrinology 2002, 143:4 I72-4I77.

17. Frasor J, Barnett DH, Danes JM, Hess R, Parlow AF, Katzenellenbogen $B S:$ Response-specific and ligand dose-dependent modulation 
of estrogen receptor (ER) alpha activity by $E R \beta$ in the uterus. Endocrinology 2003, I44:3159-3166.

18. Lund TD, Rovis T, Chung WC, Handa RJ: Novel actions of estrogen receptors-beta on anxiety-related behaviors. Endocrinology 2005, 146:797-807.

19. Shao R, Nutu M, Weijdegård B, Egecioglu E, Fernandez-Rodriguez J, Karlsson-Lindahl L, Gemzell-Danielsson K, Bergh C, Billig H: Clomiphene citrate causes aberrant tubal apoptosis and estrogen receptor activation in rat fallopian tube: implications for tubal ectopic pregnancy. Biol Reprod 2009, 80: | 262-127I.

20. Ríos M, Hermoso M, Sánchez TM, Croxatto HB, Villalón MJ: Effect of oestradiol and progesterone on the instant and directional velocity of microsphere movements in the rat oviduct: gap junctions mediate the kinetic effect of oestradiol. Reprod Fertil Dev 2007, 1 9:634-640.

21. Muscillo M, La Rosa G, Marianelli C, Zaniratti S, Capobianchi MR, Cantiani L, Carducci A: A new RT-PCR method for the identification of reoviruses in seawater samples. Water Res 200I, 35:548-556.

22. Livak KJ, Schmittgen TD: Analysis of relative gene expression data using real-time quantitative PCR and the 2(T)(-Delta Delta C) method. Methods 200I, 25:402-408.

23. Reynolds ES: The use of lead citrate at high $\mathbf{p H}$ as an electronopaque stain in electron microscopy. J Cell Biol 1963, 17:208-2I2.

24. Sierralta WD: Immunoelectron microscopy in embryos. Methods 200I, 24:6I-69.

25. Mowa CN, Iwanaga T: Differential distribution of oestrogen receptor- $\alpha$ and $-\beta$ mRNAs in the female reproductive organ of rats as revealed by in situ hybridization. J Endocrinol 2000, 165:59-66.

26. Wang H, Eriksson H, Sahlin L: Estrogen receptors alpha and beta in the female reproductive tract of the rat during the estrous cycle. Biol Reprod 2000, 63:133|-1340.

27. Kessels MM, Qualmann B, Thole HH, Sierralta WD: Subcellular localization of estradiol receptor in MCF7 cells studied with nanogold-labelled antibody fragments. Eur J Histochem 1998 42:259-270.

28. Qualmann B, Kessels MM, Thole HH, Sierralta WD: A hormone pulse induces transient changes in the subcellular distribution and leads to a lysosomal accumulation of the estradio receptor alpha in target tissues. Eur / Cell Biol 2000, 79:383-393.

29. Welshons WV, Lieberman ME, Gorski J: Nuclear localization of unoccupied oestrogen receptors. Nature 1984, 307:747-749.

30. Márquez DC, Pietras RJ: Membrane-associated binding sites for estrogen contribute to growth regulation of human breast cancer cells. Oncogen 200I, 20:5420-5430.

31. Monje P, Boland R: Subcellular distribution of native estrogen receptor $\alpha$ and $\beta$ isoforms in rabbit uterus and ovary. J Cell Biochem 200I, 82:467-479.

32. Aronica SM, Krauss WL, Katzenellenbogen BS: Estrogen action via the CAMP signaling pathway: Stimulation of adenylate cyclase and CAMP-regulated gene transcription. PNAS USA | 994, $91: 85 \mid 7-8521$.

33. Farhat MY, Abiyounes S, Dingaan B, Vargas R, Ramwell PW: Estradiol increases cyclic adenosine monophosphate in rat pulmonary vascular smooth muscle cells by a nongenomic mechanism. J Pharmacol Exp Ther 1996, 276:652-657.

34. Prakash YS, Togaibayeva AA, Kannan MS, Miller VM, Fitzpatrick LA Sieck GC: Estrogen increases $\mathrm{Ca}^{2+}$ efflux from female porcine coronary arterial smooth muscle. Am J Physiol 1999, 45:H926-H934

35. Migliaccio A, Castoria G, Di Domenico M, de Falco A, Bilancio A, Lombardi M, Barone MV, Ametrano D, Zannini MS, Abbondanza C Auricchio F: Steroid-induced androgen receptor-oestradiol receptor beta-Src complex triggers prostate cancer cell proliferation. EMBO / 2000, 19:5406-54I7.

36. Hafez ESE, Black DL: The mammalian uterotubal junction. In The Mammalian Oviduct: Comparative Biology and Methodology Edited by: Hafez, Blandau. The University of Chicago Press. Chicago; 1969:85-I28.

37. Moore GD, Croxatto HB: Effects of delayed transfer and treatment with oestrogen on the transport of microspheres by the rat oviduct. J Reprod Fertil 1998, 83:795-802.
38. Reeder RL, Shirley B: Deciliation in the ampulla of the rat oviduct and effects of estrogen on the process. J Exp Zool 1999, 283:7I-80.

39. Lyons RA, Saridogan E, Djahanbakhch O: The effect of ovarian follicular fluid and peritoneal fluid on Fallopian tube ciliary beat frequency. Hum Reprod 2006, 21:52-56.

40. Shao R, Weijdegård B, Fernandez-Rodriguez J, Egecioglu E, Zhu C, Andersson N, Thurin-Kjellberg A, Bergh C, Billig H: Ciliated epithelial-specific and regional-specific expression and regulation of the estrogen receptor- $\beta 2$ in the fallopian tubes of immature rats: a possible mechanism for estrogen-mediated transport process in vivo. Am J Physiol 2007, 293:EI47-EI58.

4I. Gonzales M, Reyes M, Damas C, Alonso R, Bello AR: Oestrogen receptor $\alpha$ and $\beta$ in female rat pituitary cells: An immunochemical study. Gen Comp Endocrinol 2008, I55:857-868.

42. Knauthe R, Diel P, Hegele-Hartung C, Engelhaupt A, Fritzemeier KH: Sexual dimorphism of steroid hormone receptor messenger ribonucleic acid expression and hormonal regulation in rat vascular tissue. Endocrinology 1996, 137:3220-3227.

43. Jesmin S, Hattori Y, Sakuma I, Liu MY, Mowa CN, Kitabatake A Estrogen deprivation and replacement modulate cerebral capillary density with vascular expression of angiogenic molecules in middle-aged female rats. I Cereb Blood Flow Metab 2003, 23:181-189.

44. Ihionkhan CE, Chambliss KL, Gibson LL, Hahner LD, Mendelsohn ME, Shaul PW: Estrogen causes dynamic alterations in endothelial estrogen receptor expression. Circ Res 2002, 91:8I4-820.
Publish with Biomed Central and every scientist can read your work free of charge

"BioMed Central will be the most significant development for disseminating the results of biomedical research in our lifetime. "

Sir Paul Nurse, Cancer Research UK

Your research papers will be:

- available free of charge to the entire biomedical community

- peer reviewed and published immediately upon acceptance

- cited in PubMed and archived on PubMed Central

- yours - you keep the copyright
BiolMedcentral 